Archived version from NCDOCKS Institutional Repository http://libres.uncg.edu/ir/asu/

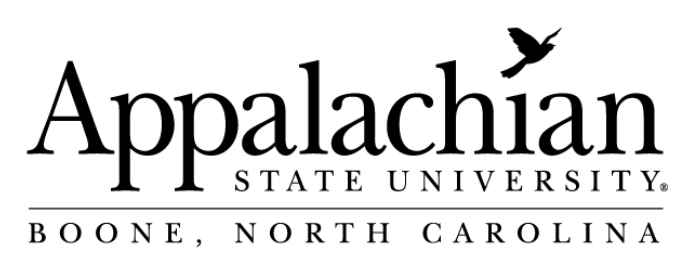

\title{
Multilateral environmental agreements and the WTO
}

By: Jayjit Roy \& Daniel Millimet

\begin{abstract}
Addressing many environmental problems requires international cooperation. However, rules under the World

Trade Organization (WTO) may deter participation in multilateral environmental agreements. Using a partial identification approach, we obtain strictly negative bounds for non-OECD countries in the WTO era.
\end{abstract}

Roy, Jayjit \& Millimet, Daniel (2015) "Multilateral environmental agreements and the WTO" Economics Letters \#134 pp. 20-23 (ISSN 0165-1765) Version of Record Available @ www.sciencedirect.com 


\title{
Multilateral environmental agreements and the WTO
}

\author{
Daniel L. Millimet ${ }^{a, b, *}$, Jayjit Roy ${ }^{c}$ \\ ${ }^{a}$ Southern Methodist University, United States \\ ${ }^{\mathrm{b}}$ IZA, Germany \\ ${ }^{c}$ Appalachian State University, United States
}

\section{highlights}

- WTO/GATT rules may limit participation in multilateral environmental agreements.

- We test this empirically while addressing self-selection and misclassification.

- To do so, we use a partial identification approach.

- WTO membership is found to inhibit MEA participation among non-OECD countries.

\section{abstract}

Addressing many environmental problems requires international cooperation. However, rules under the World Trade Organization (WTO) may deter participation in multilateral environmental agreements. Using a partial identification approach, we obtain strictly negative bounds for non-OECD countries in the WTO era.

\section{Introduction}

Little is known about the interaction between international trade agreements and domestic environmental policy. Here, we ask whether membership in the World Trade Organization (WTO) and its predecessor, the General Agreements on Tariffs and Trade (GATT), has a causal effect on participation in multilateral environmental agreements (MEAs). ${ }^{1}$ Understanding participation in MEAs is crucial as addressing many environmental problems

\footnotetext{
* Correspondence to: Department of Economics, Box 0496, Southern Methodist University, Dallas, TX 75275-0496, United States. Tel.: +1 214768 3269; fax: +1 214 7681821.

E-mail address: millimet@smu.edu (D.L. Millimet).

1 For a more general discussion of the relationship between the WTO and environmental policy, see Bernasconi-Osterwalder et al. (2006).
}

requires international cooperation (Kellenberg and Levinson, 2014).

Since World War II, more than 150 countries have joined the GATT/WTO and numerous MEAs have been formed. Over 350 international environmental agreements are currently in force; most consist of at least five countries. These time trends do not suggest a 'chilling' effect of GATT/WTO membership on MEA participation. Nonetheless, there are reasons to be concerned.First, economic theory emphasizes the need for full participation in MEAs to be successful, and this often requires punishments (or rewards) imposed through trade policies. Moreover, trade leakage due to nonparticipants may undermine MEA effectiveness (Barrett, 2005). Second, some MEAs must impede trade by definition to achieve their objectives. ${ }^{2}$ Consequently, countries may reject 
such MEAs due to fear of violating WTO rules propagating nondiscriminatory trade (Rauscher, 2005). Alternatively, MEAs designed to be compatible with GATT/WTO rules may be less appealing to countries (Eckersley, 2004).

Reasons also exist to reject the claim of a 'chilling' effect. First, Article XX of the GATT allows for measures to protect human, animal, or plant health (or life) as long as they do not discriminate in an arbitrary or unjust manner, are not a form of disguised protection, and are the least trade restrictive among alternatives. Second, if GATT/WTO membership promotes trade and economic growth, then the income effect may induce greater demand for environmental protection. Third, GATT/WTO members may participate in MEAs to avail non-tariff barriers (such as labeling requirements).

Thus, whether the WTO has a causal effect on participation in MEAs is an empirical question. However, estimation is plagued by two econometric challenges: self-selection into the GATT/WTO and misclassification of WTO membership status. While the former is straightforward, the latter is not. Interestingly, the literature on GATT/WTO membership has highlighted concerns over de jure versus de facto accession into the WTO (Tomz et al., 2007). Since misclassification of a binary treatment induces nonclassical measurement error, this is not a trivial issue (Black et al., 2000). To proceed, we utilize a nonparametric partial identification method - utilized in Kreider et al. (2012) and explained fully in McCarthy et al. (2015) - that accounts for both difficulties. It provides sharp bounds on the average treatment effect (ATE) when GATT/WTO membership is non-random and potentially misclassified. The bounds reveal exactly what can be learned under different assumptions concerning selection into treatment and the extent of misclassification. ${ }^{3}$

Utilizing data on GATT/WTO membership and participation in MEAs for roughly 200 countries over 42 years, our results are striking. First, for both OECD and non-OECD countries, we obtain positive associations between GATT/WTO membership and MEA participation when failing to account for non-random selection or misclassification. Second, all bounds considered here that allow for non-random selection into the GATT/WTO contain zero for OECD and non-OECD countries in the pre-WTO era. Third, our preferred bounds that account for non-random selection into the GATT/WTOare strictly negative for non-OECD countries in the WTO period (1995-2001) in the absence of misclassification (although the confidence intervals do contain zero). ${ }^{4}$ This suggests that WTO membership may have a chilling effect on MEA participation by less developed countries given the demands placed on them for accession to the WTO (Subramanian and Wei, 2007). The remainder of the paper is organized as follows. Section 2 presents the empirical methodology. Section 3 discusses the data. Section 4 discusses the results. Section 5 concludes.

\section{Methodology}

Our objective is to bound the ATE of GATT/WTO membership status on MEA participation, defined as

$\Delta_{X}=P \quad M\left(W T O^{*}=1\right)=1\left|X-P \quad M\left(W T O^{*}=0\right)=1\right| X$

where $P[\cdot]$ denotes the probability of the argument being true, $M$ is a binary indicator defined such that one (zero) denotes MEA participation (non-participation), and $W T O^{*}$ is a binary indicator defined such that one (zero) corresponds to true WTO membership

\footnotetext{
3 Tamer (2010) summarizes the advantages of this approach. See also Manski (2013).

4 Analysis of OECD countries in the WTO period is not possible due to insufficient variation in the data.
}

(non-membership). The probabilities are conditioned on observed covariates, $X$. We condition on OECD status and time period (preor post-WTO formation). Let $M(1) \equiv M\left(W T O^{*}=1\right)$ and $M(0) \equiv$ $M\left(W T O^{*}=0\right)$ denote potential outcomes.

Estimation of (1) is complicated due to (i) the missing counterfactual problem (i.e., $M(1)$ is notobserved if $W T O^{*}=0$ and vice versa), and (ii) the misclassification problem (i.e., observed membership, denoted by WTO, may differ from $\left.W T O^{*}\right)$. Bounds on $\Delta_{X}$ are derived under different assumptions concerning the selection process and the extent and type of misclassification. ${ }^{5}$

In terms of selection, we consider three assumptions:

(S1) Exogenous Selection (ES):

$$
M(0), M(1) \perp W T O^{*} \mid X \in \Omega
$$

where $\Omega$ denotes a particular set of values of $X$.

(S2) Monotone Treatment Selection (MTS):

$$
\begin{gathered}
P\left[M(1)=1 \mid W T O^{*}=1, X \in \Omega\right] \\
\geq P[M(1)=1 \mid W T O=0, X \in \Omega] \\
P\left[M(0)=1 \mid W T O^{*}=1, X \in \Omega\right] \\
\quad \geq P\left[M(0)=1 \mid W T O^{*}=0, X \in \Omega\right] .
\end{gathered}
$$

(S3) Monotone Instrumental Variable (MIV):

$$
\begin{aligned}
& P\left[M(1)=1 \mid v=u_{1}, X \in \Omega\right] \\
& \quad \leq P\left[M(1)=1 \mid v=u_{1} X \in \Omega\right] \\
& \quad \leq P\left[M(1)=1 \mid v=u_{2}, X \in \Omega\right] \\
& P\left[M(0)=1 \mid v=u_{1}, X \in \Omega\right] \\
& \quad \leq P[M(0)=1 \mid v=u, X \in \Omega] \\
& \quad \leq P\left[M(0)=1 \mid v=u_{2}, X \in \Omega\right],
\end{aligned}
$$

where $V$ is the MIV and $u_{1}<u<u_{2}$.

MTS assumes positive selection into treatment as the potential outcomes are at least as great in expectation in the treatment group. This is reasonable as countries often participate in MEAs and the WTO to signal credibility or a pro-growth stance. MIV assumes that potential outcomes are (weakly) monotonically increasing in $\boldsymbol{v}$. Gross Domestic Product (GDP) per capita is used as the monotone instrument, $\boldsymbol{V}$. However, given the literature on the environmental Kuznets curve (EKC), which suggests that economic growth is associated with lower (higher) environmental quality at low (high) income levels, we divide the sample into OECD and non-OECD countries (e.g., List et al., 2003). In the OECD sample, we define $V$ as GDP per capita; we assume expected MEA participation is (weakly) increasing in income. For the non-OECD sample, we define $V$ as minus GDP per capita; we assume expected MEA participation is (weakly) decreasing in income. We assess sensitivity to this choice.

In terms of misclassification, we consider two assumptions:

(M1) Upper Bound Error Rate:

$$
P\left(W T d=W T O^{*}\right) \leq Q
$$

(M2) No False Positives (NFP):

$$
W T O=1 \Rightarrow W^{*}=1 .
$$

$Q$ is the maximum allowable rate of misclassification. NFP is reasonable as we define GATT/WTO membership based on de jure membership; thus, misclassification only arises if some nonmembers act as members.

McCarthy et al. (2015) detail the derivation and estimation of the bounds on $\Delta_{X}$ under different combinations of the above assumptions, and construction of Imbens and Manski (2004) confidence intervals. We omit the details here and refer the reader.

\footnotetext{
5 Worst case bounds are also presented where the only information available concerning the missing counterfactuals are that they lie in the unit interval.
} 
Table 1

Sharp bounds on the ATE of WTO membership on MEA participation: Non-OECD, 1960-1994.

\begin{tabular}{|c|c|c|c|c|}
\hline \multirow[t]{2}{*}{ Q } & \multicolumn{4}{|c|}{ Assumptions regarding selection } \\
\hline & $\begin{array}{l}\text { Exogenous selection } \\
\text { (1) }\end{array}$ & $\begin{array}{l}\text { Worst-case } \\
\text { (2) }\end{array}$ & $\begin{array}{l}\text { MTS } \\
(3)\end{array}$ & $\begin{array}{l}\text { MTS \& MIV } \\
\text { (4) }\end{array}$ \\
\hline \multicolumn{5}{|c|}{ I. Sign a new MEA } \\
\hline 0.00 & $\begin{array}{l}{[0.098,0.098] \text { p.e. }} \\
{[0.071,0.126] \mathrm{Cl}}\end{array}$ & $\begin{array}{l}{[-0.424,0.576] \text { p.e. }} \\
{[-0.437,0.589] \mathrm{Cl}}\end{array}$ & $\begin{array}{l}{[-0.424,0.098] \text { p.e. }} \\
{[-0.437,0.121] \mathrm{Cl}}\end{array}$ & $\begin{array}{l}{[-0.338,0.025] \text { p.e. }} \\
{[-0.365,0.069] \mathrm{Cl}}\end{array}$ \\
\hline 0.01 & $\begin{array}{l}{[0.089,0.129] \text { p.e. }} \\
{[0.066,0.152] \mathrm{Cl}}\end{array}$ & $\begin{array}{l}{[-0.434,0.586] \text { p.e. }} \\
{[-0.447,0.599] \mathrm{Cl}}\end{array}$ & $\begin{array}{l}{[-0.434,0.129] \text { p.e. }} \\
{[-0.447,0.152] \mathrm{Cl}}\end{array}$ & $\begin{array}{l}{[-0.348,0.054] \text { p.e. }} \\
{[-0.375,0.097] \mathrm{Cl}}\end{array}$ \\
\hline 0.03 & $\begin{array}{l}{[0.071,0.191] \text { p.e. }} \\
{[0.048,0.213] \mathrm{Cl}}\end{array}$ & $\begin{array}{l}{[-0.454,0.606] \text { p.e. }} \\
{[-0.467,0.619] \mathrm{Cl}}\end{array}$ & $\begin{array}{l}{[-0.454,0.191] \text { p.e. }} \\
{[-0.467,0.213] \mathrm{Cl}}\end{array}$ & $\begin{array}{l}{[-0.368,0.113] \text { p.e. }} \\
{[-0.395,0.155] \mathrm{Cl}}\end{array}$ \\
\hline 0.05 & $\begin{array}{l}{[0.053,0.253] \text { p.e. }} \\
{[0.030,0.275] \mathrm{Cl}}\end{array}$ & $\begin{array}{l}{[-0.474,0.626] \text { p.e. }} \\
{[-0.487,0.639] \mathrm{Cl}}\end{array}$ & $\begin{array}{l}{[-0.474,0.253] \text { p.e. }} \\
{[-0.487,0.275] \mathrm{Cl}}\end{array}$ & $\begin{array}{l}{[-0.388,0.174] \text { p.e. }} \\
{[-0.415,0.214] \mathrm{Cl}}\end{array}$ \\
\hline \multicolumn{5}{|c|}{ II. Sign, ratify, or enter in force a new MEA } \\
\hline 0.00 & $\begin{array}{l}{[0.130,0.130] \text { p.e. }} \\
{[0.102,0.158] \mathrm{Cl}}\end{array}$ & $\begin{array}{l}{[-0.422,0.578] \text { p.e. }} \\
{[-0.434,0.591] \mathrm{Cl}}\end{array}$ & $\begin{array}{l}{[-0.422,0.130] \text { p.e. }} \\
{[-0.434,0.154] \mathrm{Cl}}\end{array}$ & $\begin{array}{l}{[-0.326,0.022] \text { p.e. }} \\
{[-0.355,0.069] \mathrm{Cl}}\end{array}$ \\
\hline 0.01 & $\begin{array}{l}{[0.115,0.155] \text { p.e. }} \\
{[0.092,0.179] \mathrm{Cl}}\end{array}$ & $\begin{array}{l}{[-0.432,0.588] \text { p.e. }} \\
{[-0.444,0.601] \mathrm{Cl}}\end{array}$ & $\begin{array}{l}{[-0.432,0.155] \text { p.e. }} \\
{[-0.444,0.179] \mathrm{Cl}}\end{array}$ & $\begin{array}{l}{[-0.336,0.046] \text { p.e. }} \\
{[-0.365,0.093] \mathrm{Cl}}\end{array}$ \\
\hline 0.03 & $\begin{array}{l}{[0.086,0.206] \text { p.e. }} \\
{[0.062,0.230] \mathrm{Cl}}\end{array}$ & $\begin{array}{l}{[-0.452,0.608] \text { p.e. }} \\
{[-0.464,0.621] \mathrm{Cl}}\end{array}$ & $\begin{array}{l}{[-0.452,0.206] \text { p.e. }} \\
{[-0.464,0.230] \mathrm{Cl}}\end{array}$ & $\begin{array}{l}{[-0.356,0.094] \text { p.e. }} \\
{[-0.385,0.142] \mathrm{Cl}}\end{array}$ \\
\hline 0.05 & $\begin{array}{l}{[0.057,0.257] \text { p.e. }} \\
{[0.034,0.281] \mathrm{Cl}}\end{array}$ & $\begin{array}{l}{[-0.472,0.628] \text { p.e. }} \\
{[-0.484,0.641] \mathrm{Cl}}\end{array}$ & $\begin{array}{l}{[-0.472,0.257] \text { p.e. }} \\
{[-0.484,0.281] \mathrm{Cl}}\end{array}$ & $\begin{array}{l}{[-0.376,0.143] \text { p.e. }} \\
{[-0.405,0.190] \mathrm{Cl}}\end{array}$ \\
\hline
\end{tabular}

Notes: p.e. = point estimates; $\mathrm{Cl}=$ confidence interval. Imbens and Manski (2004) 95\% Cls obtained using 100 bootstrap repetitions. $Q=$ maximum rate of misclassification of WTO status. Assumption of no false positives is imposed. MIV is minus GDP per capita. Number of observations $=4600$. See text for further details.

\section{Data}

Summary statistics and sources are provided in Table A1 in the Appendix. We focus on MEAs signed between 1960 and 2001 that are open (i.e., those without any participation restrictions). We consider only open MEAs to ensure that all countries face the same pool of potential agreements in which they may participate. We exclude amendments to open MEAs that entered into force via tacit acceptance provisions (i.e., without requiring explicit ratification).

The unit of observation is a country-year. The outcome, $M$, is a binary indicator if the country is a new participant in a MEA in a given year. ${ }^{6} \mathrm{~A}$ country may be counted as new participant of a particular MEA in a given year according to three distinct criteria: (i) in the year that it signs the MEA, (ii) in the year that it ratifies the MEA, and (iii) in the year that the MEA enters into force. However, a country may also withdraw from an agreement or rejoin a MEA(Mitchell, 2013). Accordingly, $M$ is defined in twoways. First, $M=1$ ifthe country signs at leastoneMEA in agiven yearon which it had taken no prior action. Second, $M=1$ if a country participates in a new MEA in a given year, where participation is defined as any of the three possibilities listed above (signature, ratification, or entry into force). The treatment indicator, WTO, is based on formal dates of accession to the WTO. The MIV, $V$, is real GDP per capita. ${ }^{7}$

A few final comments are warranted. First, using independence and dissolution dates of countries, we restrict the sample to only include countries that existed between 1960 and 2001. Second, in cases where MEAs assign multiple dates of signature, ratification, or entry into force for the same country (without any intermediate withdrawals) the earliest dates are used. Finally, an open agreement is considered to remain so for the entire sample period (Barrett, 2003).

\footnotetext{
6 Future research might consider additional analysis based on classes of MEAs. While of interest, given the inherent difficulty in grouping MEAs into unique categories we do not pursue this here.

7 The World Bank's real GDP per capita data are in 2005 US dollars. Since some of the data from other sources are in 2000 US dollars, a conversion factor based on US GDP values (obtained from the Bureau of Economic Analysis) is utilized.
}

\section{Results}

In the interest of brevity, we only display the results for the non-OECD sample. Table 1 reports the results for the pre-WTO period (1960-1994). Table 2 reports the results for the post-WTO period (1995-2001). Nonetheless, weg briefly describe the results obtained for the OECD sample as well.

We obtain several salient findings. First, for both OECD and nonOECD countries, GATT/WTO membership is positively associated with MEA participation under the assumptions of exogenous selection and no misclassification. For non-OECD countries, this continues to hold in most cases even if $5 \%$ of the control group are de facto GATT/WTO members. Second, bounds that allow for non-random selection into the GATT/WTO do not exclude zero even with the imposition of MTS or MTS-MIV and the assumption of no misclassification - for OECD and non-OECD countries in the pre-WTO era. Allowing for misclassification only further widens the bounds. Third, the point estimates of the bounds are strictly negative for non-OECD countries in the WTO period (1995-2001) in the absence of misclassification. Allowing for misclassification up to $5 \%$, the point estimates of the bounds continue to exclude zero in Panel II of Table 2. While the confidence intervals include zero, this suggests that WTO membership has a chilling effect on MEA participation by less developed countries. Finally, the results are sensitive to the choice of MIV. If expected MEA participation is assumed to be (weakly) monotonically increasing in real GDP per capita for non-OECD countries, the bounds always include zero. ${ }^{11}$

\footnotetext{
8 For the MIV bounds, the samples are divided into five GDP per capita cells. The MIV estimator is biased in finite samples, but consistent (Manski and Pepper, 2000). We use Kreider and Pepper's (2007) nonparametric finite sample bias-corrected MIV estimator (McCarthy et al. 2015).

9 Table A2 in the Appendix contains the results for the non-OECD sample over the entire sample period (1960-2001). Figs. A1-A2 plot the bounds under MTS and MTS-MIV for non-OECD countries for the full sample and the pre-WTO period. Figs. A3-A4 plot the full set of bounds for non-OECD countries in the post-WTO period. Results for the OECD sample are available upon request.

10 While the exclusion of zero from the bounds occurs only under the assumption of no misclassification in Panel I, this is more plausible in the WTO period (Tomz et al., 2007).

11 See Table A3 in the Appendix.
} 
Table 2

Sharp bounds on the ATE of WTO membership on MEA participation: Non-OECD, 1995-2001.

\begin{tabular}{|c|c|c|c|c|}
\hline \multirow[t]{2}{*}{ Q } & \multicolumn{4}{|c|}{ Assumptions regarding selection } \\
\hline & $\begin{array}{l}\text { Exogenous selection } \\
\text { (1) }\end{array}$ & $\begin{array}{l}\text { Worst-case } \\
\text { (2) }\end{array}$ & $\begin{array}{l}\text { MTS } \\
\text { (3) }\end{array}$ & $\begin{array}{l}\text { MTS \& MIV } \\
\text { (4) }\end{array}$ \\
\hline \multicolumn{5}{|c|}{ I. Sign a new MEA } \\
\hline 0.00 & $\begin{array}{l}{[0.165,0.165] \text { p.e. }} \\
{[0.115,0.215] \mathrm{Cl}}\end{array}$ & $\begin{array}{l}{[-0.445,0.555] \text { p.e. }} \\
{[-0.466,0.576] \mathrm{Cl}}\end{array}$ & $\begin{array}{l}{[-0.445,0.165] \text { p.e. }} \\
{[-0.466,0.207] \mathrm{Cl}}\end{array}$ & $\begin{array}{l}{[-0.293,-0.025] \text { p.e. }} \\
{[-0.361,0.103] \mathrm{Cl}}\end{array}$ \\
\hline 0.01 & $\begin{array}{l}{[0.149,0.192] \text { p.e. }} \\
{[0.107,0.235] \mathrm{Cl}}\end{array}$ & $\begin{array}{l}{[-0.455,0.565] \text { p.e. }} \\
{[-0.476,0.586] \mathrm{Cl}}\end{array}$ & $\begin{array}{l}{[-0.455,0.192] \text { p.e. }} \\
{[-0.476,0.234] \mathrm{Cl}}\end{array}$ & $\begin{array}{l}{[-0.303,0.011] \text { p.e. }} \\
{[-0.371,0.140] \mathrm{Cl}}\end{array}$ \\
\hline 0.03 & $\begin{array}{l}{[0.115,0.250] \text { p.e. }} \\
{[0.072,0.293] \mathrm{Cl}}\end{array}$ & $\begin{array}{l}{[-0.475,0.585] \text { p.e. }} \\
{[-0.496,0.606] \mathrm{Cl}}\end{array}$ & $\begin{array}{l}{[-0.475,0.250] \text { p.e. }} \\
{[-0.496,0.293] \mathrm{Cl}}\end{array}$ & $\begin{array}{l}{[-0.323,0.095] \text { p.e. }} \\
{[-0.391,0.221] \mathrm{Cl}}\end{array}$ \\
\hline 0.05 & $\begin{array}{l}{[0.080,0.311] \text { p.e. }} \\
{[0.036,0.357] \mathrm{Cl}}\end{array}$ & $\begin{array}{l}{[-0.495,0.605] \text { p.e. }} \\
{[-0.516,0.626] \mathrm{Cl}}\end{array}$ & $\begin{array}{l}{[-0.495,0.311] \text { p.e. }} \\
{[-0.516,0.357] \mathrm{Cl}}\end{array}$ & $\begin{array}{l}{[-0.343,0.197] \text { p.e. }} \\
{[-0.411,0.314] \mathrm{Cl}}\end{array}$ \\
\hline \multicolumn{5}{|c|}{ II. Sign, ratify, or enter in force a new MEA } \\
\hline 0.00 & $\begin{array}{l}{[0.131,0.131] \text { p.e. }} \\
{[0.081,0.181] \mathrm{Cl}}\end{array}$ & $\begin{array}{l}{[-0.395,0.605] \text { p.e. }} \\
{[-0.415,0.626] \mathrm{Cl}}\end{array}$ & $\begin{array}{l}{[-0.395,0.131] \text { p.e. }} \\
{[-0.415,0.173] \mathrm{Cl}}\end{array}$ & $\begin{array}{l}{[-0.202,-0.113] \text { p.e. }} \\
{[-0.261,0.007] \mathrm{Cl}}\end{array}$ \\
\hline 0.01 & $\begin{array}{l}{[0.103,0.147] \text { p.e. }} \\
{[0.061,0.189] \mathrm{Cl}}\end{array}$ & $\begin{array}{l}{[-0.405,0.615] \text { p.e. }} \\
{[-0.425,0.636] \mathrm{Cl}}\end{array}$ & $\begin{array}{l}{[-0.405,0.147] \text { p.e. }} \\
{[-0.425,0.189] \mathrm{Cl}}\end{array}$ & $\begin{array}{l}{[-0.212,-0.094] \text { p.e. }} \\
{[-0.270,0.028] \mathrm{Cl}}\end{array}$ \\
\hline 0.03 & $\begin{array}{l}{[0.046,0.180] \text { p.e. }} \\
{[0.002,0.224] \mathrm{Cl}}\end{array}$ & $\begin{array}{l}{[-0.425,0.635] \text { p.e. }} \\
{[-0.445,0.656] \mathrm{Cl}}\end{array}$ & $\begin{array}{l}{[-0.425,0.180] \text { p.e. }} \\
{[-0.445,0.224] \mathrm{Cl}}\end{array}$ & $\begin{array}{l}{[-0.232,-0.053] \text { p.e. }} \\
{[-0.290,0.074] \mathrm{Cl}}\end{array}$ \\
\hline 0.05 & $\begin{array}{l}{[-0.014,0.217] \text { p.e. }} \\
{[-0.060,0.262] \mathrm{Cl}}\end{array}$ & $\begin{array}{l}{[-0.445,0.655] \text { p.e. }} \\
{[-0.465,0.676] \mathrm{Cl}}\end{array}$ & $\begin{array}{l}{[-0.445,0.217] \text { p.e. }} \\
{[-0.465,0.262] \mathrm{Cl}}\end{array}$ & $\begin{array}{l}{[-0.252,-0.006] \text { p.e. }} \\
{[-0.310,0.127] \mathrm{Cl}}\end{array}$ \\
\hline
\end{tabular}

Notes: p.e. = point estimates; $\mathrm{Cl}=$ confidence interval. Imbens and Manski (2004) 95\% Cls obtained using 100 bootstrap repetitions. $Q=$ maximum rate of misclassification of WTO status. Assumption of no false positives is imposed. MIV is minus GDP per capita. Number of observations $=1135$. See text for further details.

The benefit of the partial identification approach is that it enables one to assess precisely what is learned under alternative, transparent sets of assumptions. That said, we find the results in Table 2 compelling given the negative association between income and environmental quality in lesser developed countries found in the EKC literature. Under this assumption, the strictly negative point estimates of the ATE are consistent with Subramanian and Wei (2007, p. 152): "[D]eveloping countries that wanted to join the WTO after 1994 have been required to engage in serious trade liberalization. This sets them apart from the old developing members." The authors (p. 172) continue: "A nonmember country that aspires to become a member has to make concessions and obtain approval from every existing member country. As a result, it is easier to demand that these new entrants reduce trade barriers to a greater extent than to do the same to the existing members... [P]ost-Uruguay Round accessions have indeed been qualitatively different in the sense of extracting more trade liberalizing concessions from prospective entrants.'

\section{Conclusion}

As discussed in Horn and Mavroidis (2014, p. 147), while WTO members "are legally bound to respect negotiated reductions of barriers to trade," many members are also party to MEAs "that often impose rights or obligations for members to restrict trade." Thus, the relationship between the WTO and MEAs "has created significant controversy, since neither... clarify the relationship between these sometimes, at least seemingly, contradictory undertakings." However, to our knowledge, the causal effect of WTO membership on MEA participation has not been analyzed. Using a partial identification approach, we obtain strictly negative bounds for non-OECD countries in the WTO period (1995-2001). This is consistent with the stringent demands of trade liberalization placed on new WTO members. It also implies that global integration may do little to facilitate cooperation on international environmental issues.

\section{Acknowledgments}

The authors are grateful to the editor, Pierre-Daniel Sarte, an anonymous referee, Ronald Mitchell for sharing the data on environmental agreements as well as answering their numerous questions, and comments from Dave McEvoy, seminar participants at Appalachian State University, North Carolina State University, SMU, and UNC Greensboro, and conference participants at the 2013 Southern Economic Association Meetings.

\section{Appendix A. Supplementary data}

Supplementary material related to this article can be found online at http://dx.doi.org/10.1016/j.econlet.2015.05.035.

\section{References}

Barrett, S., 2003. Environment and Statecraft: The Strategy of Environmental Treaty-Making. Oxford University Press, USA.

Barrett, S., 2005. The theory of international environmental agreements. In: Mäler, K.-G., Vincent, J.R. (Eds.), Handbook of Environmental Economics, vol. 3. pp. 1457-1516.

Bernasconi-Osterwalder, N., Magraw, D., Oliva, M.J., Tuerk, E., Orellana, M., 2006. Environment and Trade: A Guide to WTO Jurisprudence. Earthscan.

Black, D.A., Berger, M.C., Scott, F.A., 2000. Bounding parameter estimates with nonclassical measurement error. J. Amer. Statist. Assoc. 95, 739-748.

Eckersley, R., 2004. The big chill: The WTO and multilateral environmental agreements. Global Environ. Politics 4, 24-50.

Horn, H., Mavroidis, P.C., 2014. Multilateral environmental agreements in the WTO: Silence speaks volumes. Int. J. Econ. Theory 10, 147-165.

Imbens, G.W., Manski, C.F., 2004. Confidence intervals for partially identified parameters. Econometrica 72, 1845-1857.

Kellenberg, A., Levinson,, 2014. Waste of effort? International environmental agreements. J. Assoc. Environ. Resour. Economists 1, 135-169.

Kreider, B., Pepper, J., 2007. Disability and employment: Reevaluating the evidence in light of reporting errors. J. Amer. Statist. Assoc. 102, 432-441.

Kreider, B., Pepper, J., Gundersen, C., Jolliffe, D., 2012. Identifying the effects of SNAP (food stamps) on child health outcomes when participation is endogenous and misreported. J. Amer. Statist. Assoc. 107, 958-975.

List, J.A., Millimet, D.L., Stengos, T., 2003. The environmental Kuznets curve: Real progress or misspecified models?. Rev. Econom. Statist. 85, 1038-1047.

Manski, C., 2013. Public Policy in an Uncertain World. Harvard University Press, Cambridge, MA

Manski, C., Pepper, J., 2000. Monotone instrumental variables: With an application to the returns to schooling. Econometrica 68, 997-1010.

McCarthy, I., Millimet, D.L., Roy, M., 2015. Bounding treatment effects: Stata command for the partial identification of the average treatment effect with endogenous and misreported treatment assignment. Stata J., forthcoming.

Mitchell, R.B., 2013. International Environmental Agreements Database Project (Version 2013.2), http://iea.uoregon.edu/.

Rauscher, M., 2005. International trade, foreign investment, and the environment. In: Mäler, K.-G., Vincent, J.R. (Eds.), Handbook of Environmental Economics, vol. 3. pp. 1403-1456.

Subramanian, A., Wei, S.-J., 2007. The WTO promotes trade, strongly but unevenly J. Internat. Econom. 72, 151-175.

Tamer, E., 2010. Partial identification in econometrics. Annu. Rev. Econom. 2, $167-195$.

Tomz, M., Goldstein, J.L., Rivers, D., 2007. Do we really know that the WTO increases trade? Comment. Amer. Econ. Rev. 97, 2005-2018. 